\title{
Circus therapy in pediatric neuropsychological rehabilitation: an experience report
}

\author{
Circoterapia na reabilitação neuropsicológica infantil: relato de experiência \\ Terapia de circo en rehabilitación neuropsicológica infantil: informe de experiencia
}

Received: 01/29/2022 | Reviewed: 02/02/2022 | Accept: 02/11/2022 | Published: 02/17/2022

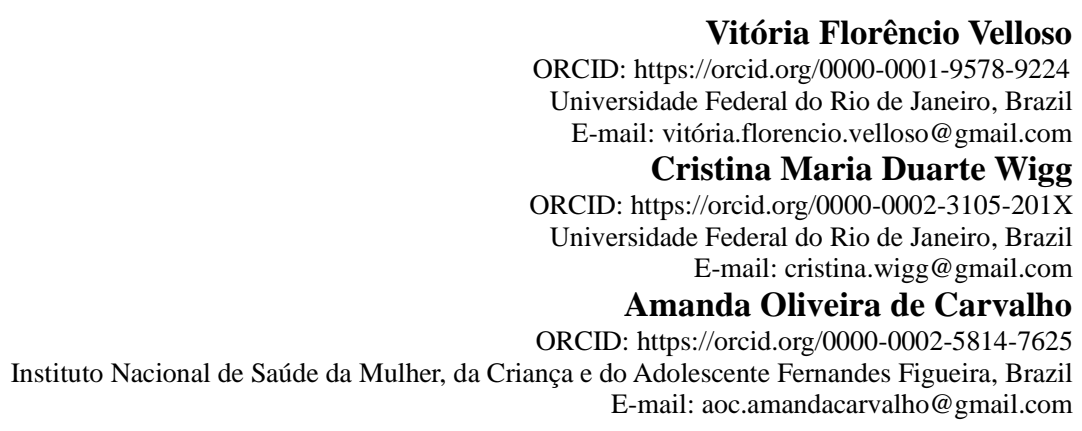

\begin{abstract}
This article reports the author's experience with the use of circus therapy activities in online neuropsychological rehabilitation of children with learning difficulties. It describes the results of free observation of one session in the PANDA Project. Four children were present, who previously underwent the neuropsychological assessment (NA) process and belong to a recurrent neuropsychological rehabilitation group. Three activities were performed in the meeting: the exhibition of a short film with paper dolls, "A Dor Azul" (The Blue Pain) (Cia dos Afetos, 2020); juggling with grocery bags; and look, feel, act (Trupe Trapia, 2021) an introductory exercise to clowning. According to the author's perception, three of the four children were more committed and motivated to participate in the proposed activities compared to the previous rehabilitation sessions, especially juggling with grocery bags. The fourth child, diagnosed with Childhood Autism (World Health Organization 1992), was resistant to most activities - except the last one, in which he was able to select an object of his interest. Based on the authors' experience, a bank of activities is being created for the permanent use of circus practices by the neuropsychological rehabilitation groups of the PANDA project.
\end{abstract}

Keywords: Circus therapy; Neuropsychological rehabilitation; Learning difficulties.

\begin{abstract}
Resumo
Este artigo relata a experiência dos autores sobre o uso de atividades de circoterapia na reabilitação neuropsicológica remota de crianças com queixa de dificuldade de aprendizagem. Ele descreve os resultados da observação livre de uma das sessões do Projeto PANDA, na qual estavam presentes quatro crianças previamente avaliadas e pertencentes a um grupo fixo de reabilitação neuropsicológica. Na sessão de reabilitação foram aplicadas três atividades: a exibição de "A Dor Azul" (Cia dos Afetos, 2020), um curta-metragem com bonecos de papel; malabarismo com sacolas de mercado; e "olhar, sentir, agir" (Trupe Trapia, 2021), um exercício de introdução à palhaçaria. De acordo com a percepção dos autores, três das quatro crianças mostraram-se mais empenhadas e motivadas a participar das atividades propostas, frente às sessões do grupo de reabilitação que não utilizavam práticas circenses, com destaque para o malabarismo com sacolas de mercado. A quarta criança, diagnosticada com Autismo Infantil (World Health Organization, 1992), mostrou-se resistente às atividades, com exceção à última, na qual pôde selecionar um objeto de seu interesse. A partir da experiência dos autores, está sendo criado um banco de atividades para uso permanente de práticas circenses nos grupos de reabilitação neuropsicológica do projeto PANDA.
\end{abstract}

Palavras-chave: Circoterapia; Reabilitação neuropsicológica; Dificuldade de aprendizagem.

\section{Resumen}

Este artículo relata la experiencia de los autores sobre el uso de actividades de terapia de circo en la rehabilitación neuropsicológica a distancia de niños con dificultades de aprendizaje. Describe los resultados de la observación libre de una de las sesiones del Proyecto PANDA, en la que estuvieron presentes cuatro niños previamente evaluados y pertenecientes a un grupo fijo de rehabilitación neuropsicológica. Durante el encuentro se realizaron tres actividades: la exhibición de "A Dor Azul" (El Dolor Azul) (Cia dos Afetos, 2020), un cortometraje con muñecos de papel; malabarismos con bolsas de supermercado; y "mirar, sentir, actuar" (Trupe Trapia, 2021), un ejercicio de iniciación al clown. Según la percepción de los autores, tres de los cuatro niños estaban más comprometidos y motivados para participar en las actividades propuestas que en las sesiones de rehabilitación anteriores, especialmente cuándo estaban 
haciendo malabarismos con bolsas de supermercado. El cuarto niño, diagnosticado con Autismo Infantil (World Health Organization 1992), se mostró resistente a las actividades - a excepción de la última, en la que pudo seleccionar un objeto de interés. A partir de la experiencia de los autores se está creando un Banco de Actividades para el uso permanente de las prácticas circenses en los grupos de rehabilitación neuropsicológica del proyecto PANDA.

Palabras clave: Terapia de circo; Rehabilitación neuropsicológica; Dificultades de aprendizaje.

\section{Introduction}

Neuropsychological Rehabilitation is an interactive process between patients and specialized professionals that aims to remedy or alleviate difficulties, adopting a holistic approach in which cognitive, emotional and psychosocial problems are treated simultaneously (Wilson, 2020). The effectiveness of neuropsychological rehabilitation is evaluated according to its ability to help the subject achieve their own personal and functional goals regarding a higher quality of life, helping the individual to build a more meaningful and pleasant life (Wilson, 2009/2020).

Circus Therapy, within the almost limitless kaleidoscope of possibilities in art therapy, presents itself as an innovative but still little explored technique. Circus games are "an activity that highlights creativity, cooperation, interculturality, body expression, as well as skills and abilities", awakening human sensations and motricity (Duprat \& Bortoleto, 2007, p.187). Diamond and Ling (2016) cite the importance of joy, a sense of social belonging and reducing stress for the development of executive functions. So, circus therapy benefits can be especially important for neuropsychological rehabilitation success.

Brant (2018) points out that stimulation through circus can be done from the practice of juggling, floor acrobatics, training exercises, clown and magic, or all together, being quite democratic and adaptable to different contexts, situations and formats. Given that, for example, improvement of executive functions from physical activities is related to the time of practice and not to the intensity of the activity (Lakes et al., 2013), therefore transfering circus activities to neuropsychological clinics should not affect these benefits significantly.

The circus, being both an art and a physical activity, is a potential offer for cognitive stimulation, expression and physical health promotion, key aspects in the development of the three executive functions and socio-emotional skills. However, as explained above there is a lack of empirical research investigating the cognitive benefits of circus modalities. Among the few existing studies, most refer to juggling. Draganski et al. (2004) analyzed juggling and its role in neuroplasticity with cognitive gains and Nakahara et al. (2007) in the treatment of anxiety. Jansen, Lange and Heil (2011) showed that juggling practice was significantly more effective in improving performance in mental rotation than simple strength training; Shi et al. (2021) observed improvement in working memory from football juggling training - a practice similar to traditional juggling in many aspects - compared to a passive control group.

The practice of circus modalities, being presented in a non-competitive and socially favorable context, showed significant improvements in behavioral and emotional problems reported by physical education teachers compared to a control group that practiced other sports (Neave et al., 2020). In Brazil, we have promising experiences involving circus in the rehabilitation of children with autism spectrum disorder being carried out at the Casulo clinic ( $O$ uso do circo no tratamento do TEA, 2020), at a school in São José, in the state of São Paulo (Aulas de circo ajudam no tratamento de crianças autistas em São José, SP, 2016) and presented in the documentary "Autismo no Trampolim" (Autism on the trampoline) (Aiquara Produções, 2021). In addition, Diamond (2015) cites different modalities of social circus as activities that can bring joy, pride, self-confidence and a sense of social belonging, key aspects to cognitive stimulation.

Introducing the experience in question, the "Projeto de Avaliação e Reabilitação Neuropsicológica de Crianças $e$ Adolescentes com Dificuldade de Aprendizagem" (Neuropsychological Assessment and Rehabilitation Project for Children and Adolescents with Learning Disabilities - PANDA), an extension project of the Federal University of Rio de Janeiro (UFRJ), 
aims to meet the demand for school problems and suspected diagnoses of learning difficulties (LD) in the city of Rio de Janeiro. PANDA assists schoolchildren aged 6 to 16 years with LD complaints, regularly enrolled in the elementary school system of Rio de Janeiro. The project provides neuropsychological assessments and neuropsychological rehabilitation, in addition to several other services. Given the social distance measures and the impossibility of face-to-face consultations due to the Covid-19 pandemic, PANDA organized online rehabilitation groups, where consultations take place through weekly video calls. Cognitive, socio-emotional and behavioral stimulation techniques are used in online rehabilitation sessions, aiming to develop autonomy, functionality and the skills involved in the learning process.

Schoolchildren are often resistant to rehabilitative activities that look like schoolwork, like pencil-and-paper exercises. With that in mind, PANDA innovated in rehabilitation techniques and strategies, introducing circus therapy activities. The circus practices were introduced not only aiming to innovate, but mainly to launch a new glance at these objects. Beyond the stimulation of skills such as attention, cognitive flexibility, and visuospatial organization, free and creative activities such as circus therapy in neuropsychological rehabilitation practices can open new paths. This contact with the unusual aims to transform the socio-emotional relationship that children have with school objects, bringing a new meaning to their thoughts and cognitions related to the academic experience.

This article aims to report a one-day experience of circus therapy practices applied during the PANDA Project (UFRJ) rehabilitation meetings in one of the project's various groups in May 2021. The experience reported here was part of the Course Conclusion Project of a PANDA extension student, who was a member of the project's rehabilitation team and responsible for the group in question (object of the ER). The extension student was under the supervision of the project's coordinator and was inspired by Aurore Romão's proposed model (2016). The circus activities, their application, and the qualitative results obtained from the children's feedback will be described. The children were part of a single group, which was accompanied by the extension student who participated in the ER. In a future article, the authors' experience with a follow-up of the same group over the period of 8 months will be reported. Considering the results of artistic and expressive interventions applied in therapeutic processes, comes the hypothesis that it is possible to operate executive functions and social skills in children at developmental age, in addition to opening space for the formation of a sense of self-efficacy and improvement in their self-esteem and well-being. As a final product, a Guide of Artistic and Expressive Practices is being created to be used both in children's clinic rehabilitation and by parents and teachers in children's ecological environments. Thus, creating alternatives for a constant and fun stimulation of skills related to learning.

\section{Methodology}

Based on the experience report (ER) script proposed by Mussi, Flores and Almeida (2021, p.5), this text contains informative descriptions, that are referenced and linked to the literature, as well as criticism of the experience in question. It aims "in addition to the description of the lived experience (near experience), its valorization by explanatory academicscientific effort, through the critical-reflective application with theoretical-methodological support (distant experience)". Thus, we carried out a search on LILACS, SCIELO and Google Scholar databases from March to November 2021. For the sake of its critical analysis, dissemination and dialogue with the academy about its different possibilities of application, we maintained a technical and scientific procedure regarding the organization of the information related to the experience of the application of circus therapy techniques. The entire context, public, time, space, proposed interventions and all other data that can be necessary for the reader to criticize it, or develop a new experience based on it, are described. The concepts are referenced and the analysis is carried out in dialogue with the literature, building up a self-criticism about the limitations and the potential of the lived intervention. 
According to Casarin and Porto (2021), "this type of text does not need approval by the research ethics committee. However, it needs to follow the current legislation regarding ethical precepts". Although the ER did not require evaluation and approval by an ethics committee, the ethical care applied included: confidentiality regarding the identification of the participants of the rehabilitation session and their families; not to induce or treat responses from questionnaires and forms for the study; not modifying the intervention environment from the ER, keeping only the routine procedure of observation and record by the extension students; not constrain or force children to participate in the activities proposed during the observed neuropsychological rehabilitation session, using only the motivational dialogues that are part of the daily rehabilitation of PANDA's children with learning difficulties.

Having said that, previously obtained information about cognitive and behavioral functions came from the database of the research project "Avaliação Neuropsicológica de Crianças e Adolescentes com Dificuldade de Aprendizagem", approved by the ethics committee of the Deolindo Couto Institute of Neurology of the Federal University of Rio de Janeiro (INDC/UFRJ), under CAAE $\mathrm{n}^{\circ}$ 0011.0.367.000.09, protocol approved 013/10, in which the observed children were participants and the authors are part of the research team.

Aiming to observe if there would be real interest in the implementation of playful circotherapy techniques of cognitive stimulation by the public of children and adolescents served by the project, a one-hour experience was planned for the ninth weekly session of one of PANDA's children's groups in May 2021. The experience took place during the period of online operations in UFRJ, due to the Covid-19 pandemic. The group was composed of four children with learning difficulties which is a multifactorial condition. They were selected for the project based on a certain demand for neuropsychological assessment (NA) and were referred for neuropsychological rehabilitation based on the cognitive and behavioral difficulties identified in the assessment. All of them previously underwent the neuropsychological assessment (NA) process and belong to one of PANDA's rehabilitation groups, being regularly monitored by two extension students. A brief description of the children's context, demands and observation data during the rehabilitation sessions can be found in chart 1.

As this article is an experience report, it only describes the quality of the children's participation in the session from the perspective of the extension student responsible for it, without any type of procedure or intervention for scientific research purposes. The quality of the children's participation in the rehabilitation session was reported from the comparison between the experience of the extension students in this session and in the previous ones, when cognitive stimulation activities inspired by the circus arts had not yet been implemented. The ER was based on a themed session, called "The Circus Day". It lasted 60 minutes, including delay tolerance at the beginning and feedback at the end. The meeting was held via Google Meet video call, at the same link and time as the other rehabilitation sessions. The link is sent weekly in a WhatsApp group with those responsible for the children, along with information about the materials needed for that day's activities. Parents were asked to bring two grocery bags and papers, which could be scratch paper or inserts. In order to observe how the children would react to the theme, it was advised that the session of that day would be themed, without specifying the theme. Aiming to contextualize the activities in the virtual environment, inspired by the model proposed by Aurore Romão (2016), the responsible extension students presented themselves with themed t-shirts. 
Chart 1. Group Description.

\begin{tabular}{ccccc}
\hline & Age & ICD-10 $^{1}$ & Undermined Functions & Relevant Socioemotional Characteristics \\
\hline Child 1 & 11 & $\begin{array}{c}\text { ICD-10 F 84.0 } \\
\text { Childhood } \\
\text { Autism }\end{array}$ & $\begin{array}{c}\text { Processing speed, executive } \\
\text { functions, attention, dealing with } \\
\text { non-verbal content, visual } \\
\text { perception, perceptual-motor } \\
\text { maturity and social skills. }\end{array}$ & $\begin{array}{c}\text { Disabilities regarding social skills in general. } \\
\text { Hyperactivity, frustration intolerance, } \\
\text { stereotyped movements, manipulation and } \\
\text { inappropriate use of objects. He is resistant to } \\
\text { rehabilitation sessions, except when the activity } \\
\text { involves directly his interests. }\end{array}$ \\
\hline Child 2 & 10 & $\begin{array}{c}\text { No confirmed } \\
\text { diagnosis. }\end{array}$ & $\begin{array}{c}\text { IQ }^{2} \text {, attention, executive } \\
\text { functions, verbal comprehension, } \\
\text { perceptual organization and } \\
\text { constructive praxis. }\end{array}$ & $\begin{array}{c}\text { Hyperactivity, low self-esteem, anxiety and } \\
\text { restlessness. Social issues at school. Good } \\
\text { behavior at home and in the rehabilitation } \\
\text { sessions. Punctual, collaborative and responds } \\
\text { well to positive feedback. }\end{array}$ \\
\hline
\end{tabular}

He is irritable, changes mood quickly, has aggressive speech, has difficulty dealing with

ICD-10 F90.0 Attention, working memory,

Child $3 \quad 13$ Disturbance of immediate memory, social skills, activity and affection and empathy. attention frustration, disagreements and concentrating on a task. Not often physically aggressive. He is quite shy and quiet in PANDA sessions; usually gives short answers when asked about a subject. He is often late for sessions, and speaks and interacts few times. He performs well on stimulation tasks in general.

\begin{tabular}{llll}
\hline Child $4 \quad 11$ & $\begin{array}{c}\text { ICD-10 F81 - } \\
\text { Specific } \\
\text { developmental } \\
\text { disorders of } \\
\text { scholastic skills }\end{array}$ & $\begin{array}{c}\text { Attention, executive functions, } \\
\text { memory, oral and written } \\
\text { language, reading and writing } \\
\text { production speed, verbal } \\
\text { comprehension and social skills. }\end{array}$ & $\begin{array}{c}\text { She is described by the family as loving, sweet } \\
\text { and friendly. She is curious and likes to learn } \\
\text { things of her interest through Youtube. She has } \\
\text { an easier time getting along with younger } \\
\text { children. She is shy, does not react well to } \\
\text { criticism and has little insight of her difficulties. } \\
\text { She has good self-esteem and is collaborative } \\
\text { during rehabilitation sessions. }\end{array}$ \\
\hline
\end{tabular}

Note. This table describes the diagnoses, compromised cognitive functions and the most outstanding socio-emotional characteristics of the four children in the group. Clinical data was obtained from the neuropsychological report prepared during the previous evaluation done by the PANDA Project. Behavioral data was described based on both clinical assessment and direct observation carried out by extension students during rehabilitation sessions. ${ }^{1}$ ICD-10: International Classification of Diseases 10th Revision. World Health Organization. (1992). The ICD-10 Classification of Mental and Behavioral Disorders. Clinical Descriptions and Diagnostic Guidelines. World Health Organization. ${ }^{2}$ IQ: Intelligence Quotient. Source: Authors (2022).

While we were waiting for all the participants to arrive, as we did in previous sessions, we started by asking the children how their week had been. We observed each reaction as the day's topic was briefly explained, and verified if the children had the required material in hand. The activities were selected and adapted from the experience of one of the authors, a PANDA extension student, who was a practitioner of circus arts. The foundations that justified the use of circus practices for the purpose of cognitive and socio-emotional stimulation were based on the studies of Duprat and Bortoleto (2007); Draganski et al. (2004); Nakahara et al. (2007); Jansen et al. (2011); Diamond, (2015); Brant, (2018); Neave et al. (2020); Shi et al. (2021) and also by reading previous practices inspired by Aurore Romão, 2016; O uso do circo no tratamento do TEA, 2020; Aiquara Produções, 2021; mainly from Aurore Romão’s proposed model. Romão (2016) emphasizes the importance of using a 
"warm-up" activity so that children become available to the more playful and relaxed nature of circus and theatrical exercises and are able to work on their emotions. That's why we planned to use a short film to introduce the session.

Three main activities and a warm-up were scheduled: exhibition of the short film "A Dor Azul" (The Blue Pain) (Cia dos Afetos, 2020), juggling with grocery bags, paper lego, and look, feel, act (Trupe Trapia, 2021). The project assumes that the schedule of rehabilitation sessions must always be adapted to the demands that arise at that moment. As this session had a slight delay due to camera difficulties of one of the participants, it was decided to exclude paper lego activity in order to provide adequate time for other activities. The activities carried out in the session were described in chart 2 .

Feedback was obtained from conversations between extension students and children at the end of the session, a practice that is part of the routine of all PANDA rehabilitation sessions. The extension student responsible - both for the session and for the experience report - recorded her observations regarding the child's participation compared to the previous sessions, immediately after the session, which is a standard practice for monitoring the PANDA rehabilitation process. The extension student's record sought to describe the quality of the child's participation in the session, highlighting: 1. If they had interacted more with colleagues and extension students; 2. If they were happy and cooperative, or resistant and annoyed; 3. Whether they were talking and being communicative during the session; 4. Whether they performed the proposed activity. In order to better illustrate the experience to the reader's understanding, the report on the children's participation in the activities was organized in tables, differentiating into verbal and non-verbal behavioral reactions for simplification purposes. In the course of the discussion, we analyzed these reactions in light of the literature and experiences from previous rehabilitation sessions. 
Chart 2. Performed Activities.

\begin{tabular}{|c|c|c|c|}
\hline Activity & Description & Stimulated Functions & Time \\
\hline $\begin{array}{l}\text { The Blue Pain (Cia } \\
\text { dos Afetos, 2020) }\end{array}$ & $\begin{array}{l}\text { Exhibition of the short film "A Dor Azul", directed by Cia } \\
\text { dos Afetos based on a short story by Adriana Falcão. Each } \\
\text { child was asked what they thought of the story and what } \\
\text { color and emotion they were feeling at the moment. } \\
\text { Psychoeducation was also carried out on how emotions } \\
\text { affect our perception of the world. }\end{array}$ & $\begin{array}{l}\text { Self-awareness, self-regulation, } \\
\text { emotional cognition, language }\end{array}$ & $10 \mathrm{~min}$ \\
\hline
\end{tabular}

This activity can be divided into three parts. Initially, the children were asked to take the sheets of paper and say an activity they used to do with it. Then, they were asked another purpose for which it could be used, as a warm-up so that they could establish a new relationship with the material. They were taught how to make homogeneously Juggling shaped balls from paper. In the second part, basic throwing techniques with up to two balls were demonstrated and practiced. In the third part, we abandoned the balls and used market bags for easier learning of more advanced maneuvers. As a warm-up for this transition, we asked the children to drop the bag and the ball on the floor and observe how long each one took to touch the floor.

Attention, hand-eye
coordination, cognitive
flexibility, visuospatial
perception and organization
perception and organization

Initially, each child was asked to pick up an object which they liked. Then, the activity was explained and

Look, Feel, Act (Trupe Trapia, 2021) demonstrated: each child should position the object next to their face. Then, look back at the camera and back at the object again, as if showing the object to other colleagues. When looking at the object for the second time, the child should demonstrate the emotion that that object caused him, and perform an action with it.
Non-verbal communication, emotional cognition, cognitive $15 \mathrm{~min}$ flexibility, theory of mind

Note. This table describes the three activities applied during the experiment. The short film "A Dor Azul" (The Blue Pain) was interpreted by Cia dos Afetos (2020) that can be found at the link: 〈https://www.youtube.com/watch? $v=n X R-1 U 4 I F 7 o \& t=2 s>$. Juggling paper balls and grocery bags are popular introductory practices. Look, Feel, Act was adapted from the activity developed by Trupe Trapia (2021) and exposed in the link: <https://www.youtube.com/watch?v=056xXxqvvlM>. Source: Authors (2022).

\section{Results and Discussion}

The current results took into account the extension student's observation about the quality of the children's participation from their behaviors and verbal manifestations carried out during each activity, in addition to the comments that emerged at the time of the feedback, described in tables 3, 4 and 5. It is noteworthy that child 1 was resistant even before knowing what the activities would be, and it was difficult for his guardian to convince him to participate in the group on that day. In view of his autism diagnosis and his emotional state at that time, such behavior could be expected. This session also occurred at the beginning of his rehabilitation's process, and some authors deal with the worsening of the behavioral resistance in autistic children during the social isolation measures in force at the moment (Ataide et al., 2021; Givigi et al., 2021). 
Chart 3. "A Dor Azul" (The Blue Pain) Short Film.

Nonverbal Behavior

\begin{tabular}{cc}
\hline & Nonverbal Behavior \\
\hline Child 1 & $\begin{array}{c}\text { Resistant behavior, loud and } \\
\text { unstable voice tone, complaints }\end{array}$
\end{tabular}

Child 2

Peaceful, silent
Verbal Behavior

When questioned, he said he "hated it" and that the story was "horrible". He couldn't say why, but he thought it was "very bad".
Color and Emotion

Yellow and

"nothing"

When asked, he said he didn't understand the

video.

Yellow and happy

Child 3

Peaceful, silent

When asked, he said the video was "nice".

Green and happy

Child 4

Peaceful, silent

When asked, she said the video was "nice".

Blue and happy

Note. Description of the children's behavioral reactions to the exhibition of the short film "A Dor Azul" (The Blue Pain), performed by Cia dos Afetos (2020) and found at the link: 〈https://www.youtube.com/watch?v=nXR-lU4IF7o\&t=2s>. Source: Authors (2022).

The other children showed emotionally neutral behavior, demonstrating that the presentation of the short story video did not have the motivating effect expected in the online format, or that the video content was not able to captivate the children. As the poetry presented was full of abstract contents which children 2 and 4 tended to have difficulties with, the child 2 's overall lack of understanding is justified, as well as the general lack of interest. The intention was to work on their language and socio-emotional skills, but the level of abstraction was too much for the group's profile.

Based on children's answers and the observed difficulty, the video was explained with a psychoeducation about emotions. When the discussion about color and the emotions that emerged during the session (in the final stage of the activity) arose, those who presented the most difficulties were children 2 and 4, who showed difficulty in dealing with verbal and abstract content. Child 3 showed a good response, which was expected given his mostly preserved cognitive skills. Child 1 was unable to adequately answer the question. He listed his favorite colors and was unable to verbally express what he felt, even when he had obvious behavioral signs of distress and anxiety such as mannerisms, raised voice, and constant complaints.

Activity two was juggling. The outstanding point of this activity was the physical effort, facial expressiveness and presence of spontaneous behavior on the child 3's execution of the exercise. In previous sessions, this child expressed himself only when asked, responding as little as necessary and maintaining a neutral emotional or boredom expression. Although he showed inappropriate behavior when he laughed at child 1's inappropriate comments, this was the first time we were able to connect with him. In addition, we were able to have a closer view of his spontaneous behavioral manifestations to be worked on in and out of rehabilitation. Therefore, that day's session was the best so far for establishing the bond and rehabilitation processes of this child.

Children 2 and 4 showed some initial resistance and insecurity, but later engaged well in the activity. This was especially relevant for child 2 , who always showed a lot of resistance, insecurity, and used to give up manual activities due to his difficulty in fine praxis. The child 2's engagement in this activity may point to good strategy possibilities to stimulate their visuospatial, attention and praxis skills. Child 4 was returning to rehabilitation that day, and our goal was to keep her eng aged to continue attending the group. We had a positive result, as she remained in the project. 
Chart 4. Juggling.

\begin{tabular}{|c|c|c|}
\hline & Nonverbal Behavior & Verbal Behavior \\
\hline Child 1 & $\begin{array}{l}\text { He did not accept to turn on the camera, the same way as in } \\
\text { previous meetings. }\end{array}$ & $\begin{array}{l}\text { When asked how he was doing, he said he didn't } \\
\text { want to do the crumpling and juggling activity } \\
\text { with the paper balls. In the grocery bag juggling } \\
\text { activity, he laughed as he said he threw the bag } \\
\text { into the ceiling fan. }\end{array}$ \\
\hline Child 2 & $\begin{array}{l}\text { Initial resistance; after more explanations and the correct } \\
\text { understanding, he was able to reproduce the movements like } \\
\text { the other children. He participated in the activity avidly, } \\
\text { repeating the exercise over and over and smiling. }\end{array}$ & $\begin{array}{l}\text { He asked for help to make the balls and showed } \\
\text { insecurity in the first launches, saying that he } \\
\text { was very bad at it. After initial resistance, he no } \\
\text { longer expressed himself verbally. }\end{array}$ \\
\hline Child 3 & $\begin{array}{l}\text { He demonstrated previous knowledge in juggling with paper } \\
\text { balls, performing advanced maneuvers with } 3 \text { balls } \\
\text { simultaneously without being asked. In juggling with a grocery } \\
\text { bag, he followed what was demonstrated. All the time he was } \\
\text { smiling, performing the movements with avidity, and repeating } \\
\text { the exercises without interruption. He laughed at child 3's } \\
\text { comments, and it was the first time he laughed in any } \\
\text { rehabilitation session. }\end{array}$ & $\begin{array}{l}\text { He did not express himself verbally, except to } \\
\text { ask for help in making the balls. }\end{array}$ \\
\hline Child 4 & $\begin{array}{l}\text { Even having some initial difficulty, she spent the time of the } \\
\text { activity smiling and performing the movements with avidity, } \\
\text { repeating the exercises without interruption. }\end{array}$ & $\begin{array}{l}\text { She did not express herself verbally, except to } \\
\text { ask for help in making the balls and in the first } \\
\text { launches. }\end{array}$ \\
\hline
\end{tabular}

Note. Description of the children's behavioral reactions to the introductory juggling activity. Source: Authors (2022).

Child 1 remained resistant to this activity, especially at first. It appears from his report that he is resistant to activities involving paper, as they are similar to school tasks. It was not possible to make him re-signify this instrument in the present session. However, the child began to show a little more enthusiasm in the activity with plastic bags. Although the participant threw the bag at the ceiling fan - one of his great interests - he also began to present more spontaneous participation. He even turned on the camera at the beginning of the next activity, which can be considered a positive attitude transformation within his individual possibilities. 
Chart 5. Look, Feel, Act (Trupe Trapia, 2021).

He turned on the camera when picking up the object of interest. As he has done in previous sessions, he put his mouth on the camera and started making noises during the explanation of the activity. It was explained to him that it counted as an action, and that it could be his action for the activity. Upon being instructed to place the Child 1 Clock object next to his face, he placed the object over his head. He followed the instruction to look at it and look back at the camera. He was confused to demonstrate what he should feel, saying that he was feeling "a lot". When it was time to reproduce the action, he did not spit at the camera again, only performing a more restrained In this activity, he didn't say much besides asking questions during the execution of the task. He was respectful as his peers performed the activity after his participation. rehearsal of this movement away from the camera.

Child 2 had difficulty understanding the command to place the object next to his face, reproducing the behavior of child 1 of

Child 2 Plush rabbit placing it on top of his head and looking up. He also had a hard time understanding what he should do in the feel stage, saying he He solved his doubts during the activity. wasn't feeling "anything". In the "action" stage, he put the rabbit in a sitting position and pointed the camera at him.

\begin{tabular}{|c|c|c|c|}
\hline Child 3 & $\begin{array}{c}\text { Game } \\
\text { controller }\end{array}$ & $\begin{array}{l}\text { Child } 3 \text { understood the task proposal well and quickly. He placed } \\
\text { the controller next to his face, confirmed with the extensionists that } \\
\text { he had gotten it right by looking straight ahead, smiled at the stage } \\
\text { of showing a feeling, and pressed the control buttons in the action } \\
\text { step. }\end{array}$ & $\begin{array}{l}\text { He solved his doubts during } \\
\text { the activity. }\end{array}$ \\
\hline
\end{tabular}

Child 4 asked for help in the look stage, but was successful to perform the attitude of looking at the object, then back at the Child 4 Ice mold camera, and then at the object again. When asked what she was feeling, she said smiling that she wasn't feeling anything. Her action

She solved her doubts during the activity. was to squeeze the holes in the silicone ice mold, laughing.

Note. Description of the children's behavioral reactions to Look, Feel, Act, adapted from the activity developed by Trupe Trapia (2021) and exposed in the link: <https://www.youtube.com/watch?v=056xXxqvvlM>. Source: Authors (2022).

Activity three was look, feel, act (Trupe Trapia, 2021). A major difficulty was that the activity had to be short, given the delay at the beginning of the meeting and the extension of previous activities. Previous sessions have shown that it is always more difficult to engage children in the last activity of the day. Given that the time for explanation and execution of the step-by-step process was short, it is possible that this exercise could have been better had it not taken place right after another long activity, such as juggling.

Child 1 showed greater engagement by being able to bring an object of interest to this activity. Despite making gestures similar to "spitting" at the camera during the explanation, this is a typical and expected mannerism of the participant. For the first time in the meeting, Child 1 turned on the camera and did what was asked. Also, he no longer reproduced his mannerism after receiving positive feedback, which showed that he had calmed down.

Child 3 began to mimic this gesture of child 1, which he had never done before. Given his report and his behavioral history, we considered this a productive result - a sign that he was feeling comfortable to act spontaneously during the meeting. 
From this approach, it will be possible for the team to better deal with his behavioral issues. Child 2 had difficulty understanding the activity, reflecting his difficulty in dealing with verbal commands and abstract contents such as emotions. Therefore, there is a need for a longer and more concrete demonstration of the activity. Child 4 excitedly did what was asked, smiling and laughing. However, she also showed difficulty with self-perception and emotional cognition, not knowing how to explain her feelings related to the object.

Given the general context, adapting circus therapy activities to the video call format was the biggest challenge. The possibilities of assistance during the execution of the activity are scarcer. In addition, the extension students can lose control of dangerous actions, such as the child throwing objects at the fan. Watching videos also becomes less interesting. However, such challenges are not very different from those presented for other online exercises, which have to compete with other distractions in the house (Solovieva et al., 2021). In addition, the circus activities had the benefit of engaging children's motivation during the session. Motivation and affectivity can help with learning retention (Tabile \& Jacometo, 2017) and encourage children to repeat rehabilitation tasks in their spare time.

Child 1, who we didn't have much success with, showed resistance even before the session started. We suspect that this resistance may have been due to frustrations the participant had in the previous week's session. Some Brazilian experiences have already suggested relevant advantages of circus therapy activities for autistic children, such as those at the Casulo clinic (O uso do circo no tratamento do TEA, 2020), at a school in São José (Aulas de circo ajudam no tratamento de crianças autistas em São José, SP, 2016), and showed at the documentary "Autismo no Trampolim" (Autism on the trampoline) (Aiquara Produções, 2021). We believe that our biggest challenge will be figuring out how to keep these gains in online operation.

The least successful activity was the exhibition of the short movie "A Dor Azul" (The Blue Pain) (Cia dos Afetos, 2020). Perhaps this type of exercise could be interesting for children's groups whose issues are predominantly behavioral, such as child 3 issues; however, it was too challenging for children who have deficits in cognitive functions related to handling abstract contents. Activities that recruit greater interaction with the images shown in the video call, or require the child to interact socially based on their own image or the image of other colleagues on camera (such as look, feel, act), proved to be difficult to handle and perform in this group, requiring greater adaptation.

The most successful activity was juggling with plastic bags, as it is dynamic, unusual and allows for different levels. Therefore, it can be easily adjusted to the zone of proximal development (ZPD) of the children in the group. According to Vygotsky (1978/1991, p. 58) the zone of proximal development encompasses "functions that have not yet matured, but are in maturation process, functions that will mature, but are currently in an embryonic state". Therefore, the ZPD includes those activities that the child can do almost alone, but still needs adult help and instruction to complete. Assistance, in this case, could be given only through verbal instructions and visual demonstrations, which was sufficient for this activity.

According to Solovieva, Rojas and Gottschalk Morais (2021), especially at this time of online operation, the criteria for choosing rehabilitation games for pediatric patients would be three: being in the zone of proximal development, being in agreement with the goals established from the neuropsychological report, and the level of the children's motivation for the game. Activity one, "A Dor Azul" (The Blue Pain), did not meet the last criterion, proving to be uninteresting and ineffective for the group. Juggling with plastic bags met the three criteria for three of the patients, proving to be an interesting activity, with an adequate level of challenge and working on attention, praxis and respect for social rules. However, this activity did not fit the strict interests of child 1, diagnosed with autism. It caused great behavioral resistance that only diminished when the child associated it with one of his objects of interest: the fan. Activity three, look, feel, act (Trupe Trapia, 2021), met the three criteria for all children by previously asking them to bring an object of their interest. It shows a viable path for the next 
PANDA's activities. However, the interest level of three of the children was not as high as in juggling, with activity three having an advantage only through its effects on child 1.

From this report, we can see a vast potential of circus practices as effective playful strategies to be used both in clinical interventions and in the daily lives of children with learning difficulties and/or developmental disorders. Children in social isolation may suffer from symptoms of stress and anxiety (Wigg et al., 2020), conditions that affect children's mental health and, therefore, their development and school performance. Given the low cost, simplicity of application and potential to generate engagement, these activities are viable even in situations of social isolation in the face of a pandemic.

\section{Final Considerations}

It can be said that the experience proved to be constructive for most children. Children 2, 3 and 4 were more committed and focused on stimulation activities, which can provide cognitive and socio-emotional gains within their long-term rehabilitation. Child 1 did not present positive responses until the last activity, in which he was able to bring an object of his choice. Given his diagnosis and his behavioral characteristics, it is plausible to suggest that he needs recreational activities that directly involve his strict interests.

The most successful activity in the online format was juggling with grocery bags. This was an unusual activity that aroused the interest of most children, and allowed a gradual increase in challenge that motivated their participation. The least successful task was the exhibition of "A Dor Azul" (The Blue Pain) (Cia dos Afetos, 2020); it was too abstract and did not meet the interests of the children in this group. The activity look, feel, act (Trupe Trapia, 2021) had advantages for using an object of choice for each child. Therefore, based on the gains observed for each activity during this initial experience, a bank of circus therapy activities is being set up to be used by the PANDA project.

For future work, it is recommended to initially propose activities that are adaptable to the most diverse interests and needs, so that the initial bond of engagement in the tasks can be formed. Activities that allow the child to choose an object that is already of direct interest to them - such as "look, feel, act" - catches their attention and works best as a warm-up. Activities that are a little different from the reality of the group in question - such as reflection on poetic content- can be better used at the end of the session, when interest in the activities has already been established. It could also be interesting to ask the children how they would have prepared the activities if they were in the extension student's place, as a way to exercise their creativity and provide good indications for the next sessions. If possible after reducing social isolation, it is recommended that such activities be administered in person, in order to provide greater support for learning and control over dangerous situations such as throwing objects used in the activity - and to allow a new look at this model of intervention.

\section{Acknowledgments}

First, we would like to thank all the interns, extension students, users and the coordinator of the PANDA Project, for all their support and trust throughout the fulfillment of this intervention. We also thank the Federal University of Rio de Janeiro (UFRJ), for providing democratic access to critical, constructive, and socially-oriented university education.

\section{References}

Aiquara Produções. (2021). Autismo no Trampolim. https://www.youtube.com/watch?v=0RDcjxPUqDw

Ataide, C. E. R., Miranda, N. T. C., Ribeiro, N. G. da S., Farias, L. F., Gama, B. T. B., \& Montenegro, K. S. (2021). Impacto do distanciamento social na rotina de crianças e adolescentes com Transtorno do Espectro Autista. Research, Society and Development, 10(16), e115101623242. https://doi.org/10.33448/rsd-v10i16.23242

Aulas de circo ajudam no tratamento de crianças autistas em São José, SP. (2016, September 5). G1; Globo. http://g1.globo.com/sp/vale-do-paraibaregiao/noticia/2016/09/aulas-de-circo-ajudam-no-tratamento-de-criancas-autistas-em-sao-jose-sp.html 
Aurore Romão, R. (2016). Jogos Teatrais Na Pediatria, Brincando com os Objetos do Teatro: Dispositivos para Cuidar. https://pesquisa.bvsalud.org/portal/resource/pt/biblio-1026685

Brant, D. V. da S. B. D. V. da S. (2018). Arte Circense como Recurso Terapêutico no

Atendimento de Crianças com Transtorno do Espectro Autista. Revista Saúde e

Educação, 3(2). https://ojs.fccvirtual.com.br/index.php/REVISTA-SAUDE/article/view/259

Casarin, S. T., \& Porto, A. R. (2021). Relato de Experiência e Estudo de Caso: algumas considerações. . J. Nurs. Health., 11(2). https://doi.org/HTTPS://DOI.ORG/10.15210/JONAH.V11I4.21998

Cia dos Afetos. (2020). A Dor Azul. https://www.youtube.com/watch?v=nXR-1U4IF7o\&t=2s

Diamond, A. (2015). Effects of Physical Exercise on Executive Functions: Going beyond Simply Moving to Moving with Thought. Annals of Sports Medicine and Research, 2(1), 1011. https://www.ncbi.nlm.nih.gov/pmc/articles/PMC4437637/

Diamond, A., \& Ling, D. S. (2016). Conclusions about interventions, programs, and approaches for improving executive functions that appear justified and those that, despite much hype, do not. Developmental Cognitive Neuroscience, 18, 34-48. https://doi.org/10.1016/j.dcn.2015.11.005

Draganski, B., Gaser, C., Busch, V., Schuierer, G., Bogdahn, U., \& May, A. (2004). Changes in grey matter induced by training. Nature, 427(6972), 311-312. https://doi.org/10.1038/427311a.

Duprat, R. M., \& Bortoleto, M. A. C. (2007). Educação Física Escolar: Pedagogia e Didática das Atividades Circenses. Revista Brasileira de Ciências Do Esporte, 28(2), 187. http://revista.cbce.org.br/index.php/RBCE/article/view/63

Givigi, R. C. do N., Silva, R. S., Menezes, E. da C., Santana, J. R. S., \& Teixeira, C. M. P. (2021). Efeitos do isolamento na pandemia por COVID-19 no comportamento de crianças e adolescentes com autismo. Revista Latinoamericana de Psicopatologia Fundamental, $24(3)$, 618-640. https://doi.org/10.1590/1415-4714.2021v24n3p618.8

Jansen, P., Lange, L. F., \& Heil, M. (2011). The Influence of Juggling on Mental Rotation Performance in Children. Biomedical Human Kinetics, 3, 18-22. https://eric.ed.gov/?id=EJ918148

Lakes, K. D., Bryars, T., Sirisinahal, S., Salim, N., Arastoo, S., Emmerson, N., Kang, D., Shim, L., Wong, D., \& Kang, C. J. (2013). The Healthy for Life Taekwondo pilot study: A preliminary evaluation of effects on executive function and BMI, feasibility, and acceptability. Mental Health and Physical Activity, 6(3), 181-188. https://doi.org/10.1016/j.mhpa.2013.07.002

Mussi, R. F. de F., Flores, F. F., \& Almeida, C. B. de. (2021). Pressupostos para a Elaboração de Relato de Experiência como Conhecimento Científico. Práxis Educacional, 17(48), 1-18. https://doi.org/10.22481/praxisedu.v17i48.9010

Nakahara, T., Nakahara, K., Uehara, M., Koyama, K., Li, K., Harada, T., Yasuhara, D., Taguchi, H., Kojima, S., Sagiyama, K., \& Inui, A. (2007). Effect of juggling therapy on anxiety disorders in female patients. BioPsychoSocial Medicine, 1(1), 10. https://doi.org/10.1186/1751-0759-1-10

Neave, N., Johnson, A., Whelan, K., \& McKenzie, K. (2020). The psychological benefits of circus skills training (CST) in schoolchildren. Theatre, Dance and Performance Training, 11(4), 1-10. https://doi.org/10.1080/19443927.2019.1666027

O uso do circo no tratamento do TEA. (2020, February 26). CASULO - Comportamento \& Saúde. http://casulocs.com.br/blog/o-uso-do-circo-no-tratamentodo-tea

Shi, Y., Cai, K., Zhu, H., Dong, X., Xiong, X., Zhu, L., Sun, Z., \& Chen, A. (2021). Football Juggling Learning Alters the Working Memory and White Matter Integrity in Early Adulthood: A Randomized Controlled Study. Applied Sciences, 11(9), 3843. https://doi.org/10.3390/app11093843

Solovieva, Y., Rojas, L. Q., \& Morais, C. P. G. (2021). Reflexiones sobre las posibilidades de una práctica de la neuropsicología infantil en línea. Neuropsicologia Latinoamericana, 13(2). https://www.neuropsicolatina.org/index.php/Neuropsicologia_Latinoamericana/article/view/645/315

Tabile, A. F., \& Jacometo, M. C. D. (2017). Fatores influenciadores no processo de aprendizagem: um estudo de caso. Revista Psicopedagogia, 34(103), 7586. http://pepsic.bvsalud.org/scielo.php?script=sci_abstract\&pid=S0103-84862017000100008

Trupe Trapia. (2021). Circo em casa - Exercícios de palhaçaria - olhar, sentir, agir. https://www.youtube.com/watch?v=056xXxqvvlM

Vygotsky, L. (1991). A Formação Social da Mente (4th ed., p. 58). Livraria Martins Fontes Editora Ltda. (Original work published 1978)

Wigg, C. M. D., Coutinho, I. M. F. de A.., Silva, I. C. da, \& Lopes, L. B. (2020). A saúde mental de crianças e adolescentes durante pandemia COVID-19: uma revisão narrativa. Research, Society and Development, 9(9), e704997687. https://doi.org/10.33448/rsd-v9i9.7687

Wilson, B. A. (2020). Reabilitação neuropsicológica: teoria, modelos, terapia e eficácia (pp. 9-12). Artesã Editora. (Original work published 2009)

Wilson, B. A. (2020). Neuropsychological Rehabilitation for People with Non-Progressive Brain Damage. Oxford Research Encyclopedia of Psychology. https://doi.org/10.1093/acrefore/9780190236557.013.720

World Health Organization. (1992). The ICD-10 Classification of Mental and Behavioral Disorders. Clinical Descriptions and Diagnostic Guidelines. World Health Organization. 